\title{
Incidence of Pigeon Pea Yellow Mosaic Disease and Vector Population from Chhattisgarh, India
}

\author{
Palaiyur Nanjappan Sivalingam ${ }^{*}$, Yogesh Yele ${ }^{1}$, R.K. Sarita ${ }^{2}$ \\ and Kailash Chander Sharma ${ }^{1}$
}
${ }^{1}$ ICAR-National Institute of Biotic Stress Management, Baronda, Raipur-493225, Chhattisgarh ${ }^{2}$ ICAR-Indian Agricultural Research Institute, PUSA, New Delhi-110012

*Corresponding author

\section{A B S T R A C T}

\begin{tabular}{|l|}
\hline Ke y w or d s \\
Chhattisgarh, \\
Pigeon pea yellow \\
mosaic disease, \\
whitefly, PCR, \\
vector
\end{tabular}

\begin{abstract}
Pigeon pea is an important drought tolerant pulse crop. Yellow mosaic disease (PYMD) was appeared in the farmers' field of Chhattisgarh. Present study aimed to record incidence \& identify causal agent associated with PYMD and reason for low disease incidence. Survey and symptomatology was recorded in the farmers' field of Chhattisgarh. PYMD incidence and vector population was recorded in the experimental field of ICARNIBSM, Raipur during summer 2017. Causal agent associated with PYMD was identified by PCR. Symptoms of PYMD was characterized as yellow mosaic, mottling, shortening of leaves and stunting, the disease incidence recorded in Chhattisgarh state was between 1.5 and 6.1 per cent and whitefly vector population was recorded as 1.8 to 3.2 per plant, causal agent associated with PYMD identified as begomovirus. Low incidence of PYMD in field, high vector population and positive PCR amplification by primers specific to begomovirus infecting tomato suggest that the begomovirus infecting tomato may be adapting to pigeon pea, a non-host species. This is the first report of the occurrence yellow mosaic disease in pigeon pea in the central India particularly in Chhattisgarh.
\end{abstract}

\section{Introduction}

Pigeon pea (Cajanus cajan L. Millsp) is an important drought resistant leguminous food crop, used both for dhal and also vegetable purpose. At global level pigeonpea occupied 6.22 $\mathrm{M}$ ha in 22 countries and mostly in Asia and Africa. But India alone covers more than $70 \%$ area $(4.65 \mathrm{M} \mathrm{ha})$ among all pigeonpea growing countries (FAOSTAT, 2013). The crop is known to be affected by more than 50 diseases (Nene et al., 1981). Among which yellow mosaic disease of pigeonpea is reported to be emerging in several agroclimatic zones of India (Biswas et al., 2008). Occurrence of yellow mosaic disease of pigeon pea (PYMD) was first described by Williams et al., (1968). Later Nene et al., (1971) reported that the yellow mosaic of pigeon pea was caused by mungbean yellow mosaic virus (MYMV) on the basis of white fly (Bemisia tabaci) transmission and 
symptomatology. It is reported from northern and southern parts of Delhi, Uttar Pradesh, Andra Pradesh and Karnataka (Muniyappa and Veeresh, 1984; Manjunatha et al., 2015). The virus was detected in the naturally infected pigeon pea plants and the geminate particles were measuring 15-18 X 30nm (Muniyappa et al., 1987).

The infection of Mungbean yellow mosaic India virus (MYMIV) in the pigeon pea cultivars through whitefly transmission was achieved from mungbean infected with MYMIV as source plant (Biswas et al., 2008). On the basis of coat protein sequence of begomovirus causing yellow mosaic disease in pigeon pea in Karnataka was found closely related to Horse gram yellow mosaic virus and Mung bean yellow mosaic virus (Manjunatha et al., 2015). However, the begomovirus causing yellow mosaic disease in horsegram could not be transmitted by whitefly to pigeon pea and also to green gram and blackgram (Prema and Rangasamy, 2017). The virus was transmitted to healthy pigeon pea seedlings from the symptomatic plants by whitefly (Raj et al., 2005). Coat protein gene sequence from these plants was found closely related to various strains of Tomato leaf curl New Delhi virus (ToLCNDV). The incidence of PYMD and in relation to population dynamics to whitefly vector was not known, this is paramount important in the management of PYMD. Here we report the periodical PYMD incidence and whitefly population, and detection of begomovirus in the infected samples.

\section{Materials and Methods}

\section{Survey, symptomatology, disease incidence and whitefly populations}

The surveys were carried out to monitor the incidence of yellow mosaic disease in pigeon pea in the farmers' fields of Chhattisgarh. The symptomatology was recorded as appeared in the field. The yellow mosaic disease incidence in pigeon pea cv AL15 was recorded during summer 2017 in the experimental farm of ICAR-National Institute of Biotic Stress Management, Raipur. The disease incidence was recorded in 20 spots by counting number of plants showing yellow mosaic symptoms out of 50 plants per spot. Similarly whitefly population was also counted in the randomly selected 20 spots and in each spot the whitefly was counted per plant. In each plant three leaves were selected for counting whiteflies, one each at top, middle and bottom.

\section{Total DNA extraction and PCR detection}

The total DNA was extracted from symptomatic and asymptomatic leaves of pigeon pea cV AL15 by CTAB method as described by Doyle and Doyle (1990) with minor modifications. The total DNA extracted from $100 \mathrm{mg}$ leaf tissue by liquid nitrogen and mixed with CTAB buffer along with RNase followed by incubation at $65^{\circ} \mathrm{C}$ for 1 $\mathrm{hr}$. The supernatant was transferred to another tube and added equal amount of chloroform: isoamyl alcohol (24:1) mixed for 20 minutes and centrifuged. The DNA precipitated and stored in $1 \mathrm{X}$ TE buffer at $-20^{\circ} \mathrm{C}$. Polymerase chain reaction was done in $25 \mu 1$ containing $100 \mathrm{ng}$ of total DNA, 2mM dNTP,10 pmoles of each primers specific to begomovirus infecting tomato (Forward- ToLCPFAAGATATGGATGGATGAGAAC;

Reverse-

ToLCPRACATAATTATTAACCCTAACAA), 1x Taq DNA Buffer, 1.0 unit of Taq DNA polymerase, $25 \mathrm{mM} \mathrm{MgCl}_{2}$. The PCR was done as initial denaturation of $94^{\circ} \mathrm{C}$ for 5 minutes followed by 30 cycles of denaturation $94^{\circ} \mathrm{C}$ for 1 minute, annealing $55^{\circ} \mathrm{C}$ for 1 minutes and extension $72^{\circ} \mathrm{C}$ for 2 minutes and final extension of $72^{\circ} \mathrm{C}$ for 10 minutes. The PCR products was loaded on to $1 \%$ agarose 
gel, electrophoresed and viewed under UV transilluminator and recorded.

\section{Results and Discussion}

Among the 22 districts surveyed, the incidence of yellow mosaic disease of pigeon pea was observed and recorded in Rajnandgaon, Kanker and Jagadalpur districts of Chhattisgarh was 3.1, 1.5 and 5.0 per cent, respectively. The incidence of PYMD was recorded low in the field conditions of Chhattisgarh, Andhra Pradesh, Karnataka and Delhi. The disease incidence based on roving survey of different pigeon pea fields in the Kolar district of Karnataka during kharif 2014-15recordedfrom 1-5 percent (Manjunatha et al., 2015). The incidence observed based on phenotypic appearance of the symptoms. However, in the most of the cases the no phenotypic symptom expression observed in pigeon pea under field condition, but the presence of begomovirus in the asymptomatic plants have been reported (Biswas et al., 2008). This might be due to the age of the plants, host mechanism operating against these viruses. In this study the PYMD incidence in the experimental farm of ICARNIBSM was between 1.5 to 6.1 per cent. The symptoms of the disease recorded as yellow mosaic, mottling, shortening of leaves with stunting and produce only few pods (Figure 1a). These symptoms were closely related to the symptoms of other yellow mosaic legume viruses. The symptoms depend on the host and susceptibility (Nene, 1972; Muniyappa et al., 1976; Singh et al., 2002; Javaria et al., 2007). The virus causing PYMD was successfully transmitted from infected plants to pigeon pea seedlings that produce typical disease symptoms, but not by mechanical inoculations (Raj et al., 2005).

The average of whitefly vector population per plant was observed in this study during March to June 2018 that ranged between 1.8 and 3.2. It indicates that the sufficient whitefly population was present for transmission of virus during the period of disease observation. The possibility of symptomless plants in the field could not be ruled out as they were not tested by the presence of begomovirus. Some of the symptomatic pigeon pea plants showed yellow mosaic were recovered and showed no symptoms of yellow mosaic. This could be one of reasons for lower incidence recorded during April and June (Table 1) though the enough whitefly populations available during this period.

Table.1 Average percent disease incidence and whitefly population in the field

\begin{tabular}{|l|c|c|}
\hline Date of observation & Percent PYMD incidence* \pm SE & Average whitefly per plant ${ }^{\#} \pm \mathbf{S E}$ \\
\hline 21st March 2018 & $6.1 \pm 1.00$ & $2.05 \pm 0.39$ \\
\hline 30th March 2018 & $5.1 \pm 1.13$ & $3.2 \pm 0.49$ \\
\hline 11th April 2018 & $1.5 \pm 0.35$ & $2.1 \pm 0.40$ \\
\hline 06th June 2018 & $2.6 \pm 0.63$ & $1.8 \pm 0.34$ \\
\hline
\end{tabular}

SE- Standard Error

* average of randomly selected 20 spots observed and each spot contains randomly selected 50 plants.

${ }^{\#}$ average number of whiteflies present on the randomly selected 20 plants; SE- Standard error 
Fig.1 (A) Pigeon pea yellow mosaic symptomatic plant (left) apparently healthy plants (right), (B) Detection of begomovirus by PCR amplification of coat protein region. Lane M-1Kb DNA ladder; Lane D- DNA extracted from PYMD leaf sample; Lane AH1-AH2- DNA extracted from apparently healthy plant leaves

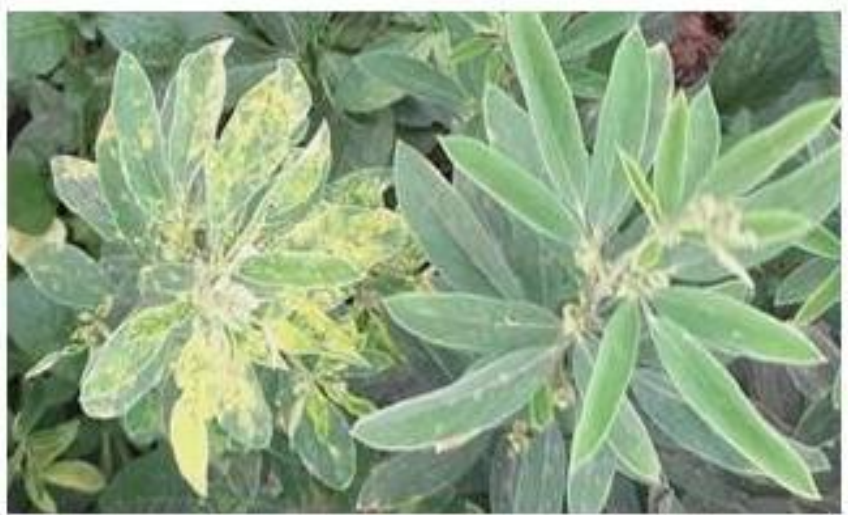

A

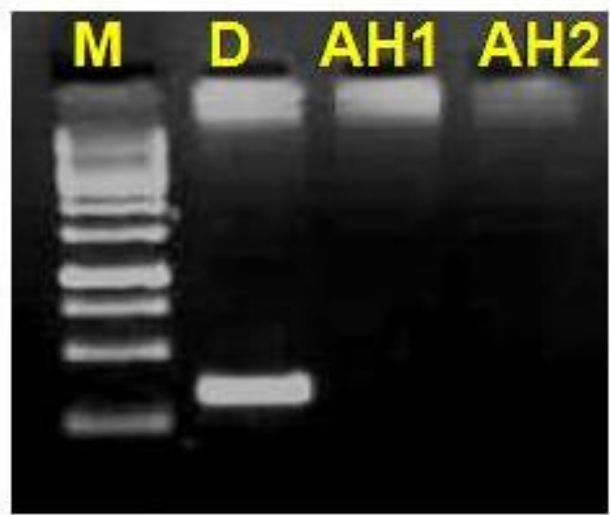

B
The DNA from yellow mosaic leaves was showed the positive amplification with the coat protein gene primers specific to begomoviruses infecting tomato (Figure 1b). However, no PCR amplifications was observed from DNA isolated from apparently healthy plant leaf samples. Raj et al., (2005) found that the sequence of PCR amplified product from PYMD samples was closely related to ToLCNDV and the DNA of infected samples hybridized with the probe of ToLCNDV. Comparison of results obtained here with the earlier studies, the possible causal agent of PYMD in Chhattisgarh could be begomovirus infecting tomato. This is the first report of the occurrence yellow mosaic disease in pigeon pea in the central India particularly in Chhattisgarh.

\section{Acknowledgement}

Authors thank to Director and Joint Director (Research), ICAR-NIBSM) for providing necessary facilities to conduct research. This is ICAR-NIBSM contribution number NIBSM/RP-14/2018-6.

\section{References}

Biswas, K.K., Malathi, V.G. and Varma, A. 2008. Diagnosis of Symptomless Yellow mosaic begomovirus Infection in Pigeonpea by Using Cloned Mungbean yellow mosaic India virus as Probe. J. Plant Biochemistry \& Biotechnology. 17: 09-14.

Doyle, J.J. and Doyle, J.L. 1990. Isolation of plant DNA from fresh tissue. Focus.12: 13-15.

Javaria, Q., Muhammed, I., Shaid M., and Briddon, R.W. 2007. Legume yellow mosaic viruses: genetically isolated begomoviruses. Mol. Pl. Pathol. 84: 343-348.

Manjunatha, N., Haveri, N, Reddy B.A., Archana, S. and Manjunath, S. H. 2015. Molecular Detection and Characterization of Virus Causing Yellow. Int. J. Pure App. Biosci. 3: 258-264.

Muniyappa, V. and Veeresh, G.K. 1984. Plant virus diseases transmitted by whiteflies in Karnataka, Proceedings 
of the Indian Academy of Sciences (Animal Science). 93: 397-406.

Muniyappa, V., Rajeshwari, R., Bharathan, N., Reddy, D.V.R. and Nolt, B.L. 1987. Isolation and characterization of Gemini virus causing yellow mosaic disease of horsegram (Macrotyloma uniflorum (Lam.) Verdc.) in India. Journal of Phytopathology. 119: 8187.

Muniyappa, V., Reddy, H.R., and Shivashankar, G. 1976. Yellow mosaic disease of horse gram. Curr. Res. 4: 176.

Nene, Y.L. 1972. A study of viral diseases of pulse crops in Uttar Pradesh. Res. Bull., No.4. G. B. Pant.Unvi. Agri. Tech., Pantnagar, pp. 144.

Nene, Y.L., Kannaiyan, J. and Reddy, M.V. 1981. Pigeon pea diseases resistance screening techniques. Information Bulletin No.9. Pattancheru, AP, India, ICRISAT.

Nene, Y.L., Naresh, J.S. and Nair, N.G. 1971. Additional host of mungbean yellow mosaic virus. Indian Phytopathol. 24: 415-417.
Prema G. U. and Rangaswamy K.T. 2017. Field Evaluation of Horsegram Germplasm/ Genotypes against Horsegram Yellow Mosaic Virus (HgYMV) Disease and Biological Transmission of Horse Gram yellow Mosaic Virus to Different Leguminous Hosts through White Flies. International Journal of Agriculture Sciences. 9: 4934-4939.

Raj, S.K., Khan, M.S. and Singh, R. 2005. Natural occurrence of a begomovirus on Pigeonpea in India. New Disease Reports. 11: 4.

Singh, R.A., Rajib K.D.E., Gurha, S.N. and Ghosh, A. 2002. Yellow mosaic of mung bean and urd bean. IPM system in agriculture. 8: 395-408.

Sudhakar Rao, A., Prasad Rao, R.D.V.J. and Reddy, P.S. 1980. Whitefly transmitted yellow mosaic of groundnut (Arachi shypogea L.), Curr. Sci. 49: 160.

Williams, F.J., Grewal, J.S. and Amin K.S. 1968. Serious and new diseases of pulse crops in India in 1966. Plant Dis. Reptr. 52: 300-304.

\section{How to cite this article:}

Palaiyur Nanjappan Sivalingam, Yogesh Yele, R.K. Sarita and Kailash Chander Sharma. 2019. Incidence of Pigeon Pea Yellow Mosaic Disease and Vector Population from Chhattisgarh, India. Int.J.Curr.Microbiol.App.Sci. 8(02): 1699-1703.

doi: https://doi.org/10.20546/ijcmas.2019.802.199 